\title{
The early benefits of agroforestry as the solution of social conflict and peat land degradation in Kampar - Riau, Indonesia
}

\author{
Ahmad Junaedi, Andhika Silva Yunianto* and Hery Kurniawan \\ Research and Development Institute of Forest Fiber Technology, Jln. Raya Bangkinang - Kuok KM.9 \\ Bangkinang 28401 Kotak Pos 4/BKN - Riau
}

\begin{abstract}
Agroforestry has been mentioned has good potency to be selected as one of the tools to overcome the problem of degraded tropical peat swamp forest (TPSF) which was associated with social conflict. Here, we evaluated the early benefits of agroforestry for some aspects which has relationship with the attempt to overcome social conflict and peatland degradation*. We established the experimental plot of agroforestry in the conflict area at forest area with special purpose (KHDTK) in Kepau Jaya Village, Kampar District, Riau Province. We planted three native tree species of TPSF, namely were Balangeran (Shorea balangeran), Geronggang (Cratoxylum arborescens) and Gelam (Melaleuca cajuputi subsp. cumingiana. In this plot, between rows of tree plantation the local farmer cultivated their crop. At 11 months after plantation; the ranges of survival rate, height and collar diameter increment of all tree native species were $56.2 \%$ - 72.44\%, $97.4 \mathrm{~m} /$ year $-163.0 \mathrm{~m} /$ year and $2.04 \mathrm{~cm} /$ year -3.2 $\mathrm{cm} /$ year, respectively. Furthermore, from the yields of the three types of seasonal crops (melon, chilli and luffa), the average income which was gathered by farmers was of $6,000,000 \mathrm{IDR}$. We also observed that during this agroforestry activity, the intensity of forest disturbance by the local community around KHDTK was relatively reduced. It is important to manage and increase those diverse benefits in further years.
\end{abstract}

Keywords: Agroforestry, farmer, native tree species and social conflict

\section{Introduction}

The area of degraded peatland in Indonesia must be reduced due to it associated with fire and haze disaster. It was related to the fact that the more prone condition to fire will exhibited in the degraded peatland than that in healthful peatland. Furthermore, when the fire and haze disaster was occurred, several negative impacts on the aspects of ecology, social and economic will be produced. For instance, the economic losses of Indonesia as the impact of fire disaster at the years of 2013, 2015 and 2020 were 1.49, 16.00 and 5.20 billion USD, respectively $[1,2,3]$. The fire disaster of Indonesian peatland also contributed $(8 \%)$ to the increasing of global carbon emission [4].

\footnotetext{
* Corresponding author: andhikasilva@ gmail.com
} 
Riau is one of the provinces in Indonesia which has vast area of degraded peatland. As the example, the degraded peat forest at 2009 - 2013 period only was 450 thousand ha and it was the largest in Indonesia [5]. Moreover, the total of degraded peatland in Riau was about 2.31 million ha [6]. Rehabilitation must be undertaken to reduce this vast are of degraded peatland.

The government of Indonesia has three strategies in order to rehabilitate degraded peatland; namely are rewetting, re-vegetation and revitalization of livelihoods [7]. These strategies can be implemented on field through agroforestry practice, especially in the conflict area where concern must be also given to overcome social problem. It is reasonable due to the agroforestry practice has been proven can give a lot of ecology, social and economic advantages [8-11]. However, this practice was relatively less familiar in Riau than that in other regions such as in Java, South Sumatra and Kalimantan. Therefore, the insight that related to the capability of agroforestry to improve degraded peatland and livelihood community in Riau was relatively still limited. To reduce this gap, we collaborated to establish an agroforestry trial with local farmer who was lived around a conflict area of degraded peatland in Kampar, Riau. Here, we investigated the early benefits which exhibited in this agroforestry trial. This investigation is the part of long study which will be conducted to obtain an appropriate agroforestry model which will be implemented at this conflict area.

\section{Material and method}

\subsection{Site Study}

The study was carried out in a trial (experimental plot) which was established at October 2019 at conflict area in forest area with special purpose/kawasan hutan dengan tujuan khusus (KHDTK) in Kepau Jaya Village, Kampar District, Riau Province. The location of experimental plot land used is at N. $00^{\circ} 18$ ' $18,9^{\prime \prime}$ E. $101^{\circ} 27^{\prime} 48,6^{\prime \prime}$ coordinate point of centre of plot, with the elevation is $12 \mathrm{~m}$ asl. This plot is about $20 \mathrm{~km}$ of Pekanbaru (the capital of Riau Province). Climate type of the location is A (based on Schmidt-Ferguson classification), with the average of annual rainfall were $2324 \mathrm{~mm}$ and the range of temperature and relative humidity were $20-34^{\circ} \mathrm{C}$ and $48-99 \%$. The soil is histosol with the domination of class of maturity is sapric. The peatland in location has been drained, but the water level was maintained to persist less than $50 \mathrm{~cm}$ below soil surface.

The previous condition of peatland in the location prior trial establishment was secondary forest. However, further, this forest was cut by illegal logger for oil palm plantation. However, this land was abandoned with the final condition of land prior plot establishment was dominated the understory vegetation of shrubs, Imperata cylindrica, grasses and fern.

\subsection{Establishment of agroforestry trial}

We have been using an approximately 2.7 ha for the trial (agroforestry plot). For the establishment of plot, we collaborate with the local farmers who were joined in community Forestry Farmer Group (kelompok tani hutan/KTH) namely KTH Tuah Tani Tonggak Negeri. The preparation of plot was done manually. Undesired understory were cleared by traditional farming tools and further sprayed with herbicide. At the October 2019, in this relatively clear land, the plantation of forest species was undertaken.

As the forest species, we chosen three native tree species of tropical peat swamp forest, namely were balangeran (Shorea balangeran), geronggang (Cratoxylum arborescens) and gelam (Melaleuca cajuputi subsp. cumingiana). Those three native tree species are 
promising species for rehabilitation of degraded peatland due to had relatively promising growth and also their wood and noon wood has several uses. Balangeran wood can be used for the material of furniture, house and bridge [12]. The wood of Geronggang could be used for light-intermediate components of house building and its fiberwood had good potency for pulp raw material $[13,14]$. Beside of that, the flower of Geronggang is one of favorite flowers to honey bee [15]. The pole of Gelam was widely used for house construction, while the timber also used for board and beam [16]. The leaves of Gelam could produces oil gelam that has good potency for pharmaceutical industry raw material, despite this oil content was very low [17].

The three native tree species were planted in similar planted spacing $(6 \mathrm{~m} \times 3 \mathrm{~m})$ at the field with the arrangement refer to a Randomized Completely Block Design (RCBD). The treatments were $\mathrm{A}=$ Gelam, $\mathrm{B}=$ Geronggang, $\mathrm{C}=$ Balangeran and $\mathrm{D}=$ Mixed species of $\mathrm{A}+\mathrm{B}+\mathrm{C}$, with the number of replication were three blocks. Around the edge of the plot, we also planted the Liberica Coffee (Coffea excelsa) and Aren (Arenga pinnata). In this plot, between rows of tree plantation the local farmer (members of KTH) cultivated their crop. For this crop cultivation, the kinds of crops and its cultivation technique were selected based on farmer interest. Several cultivated crop were Melon, Chili pepper, Corn, Cucumber, Luffa (gambas) and Cassava.

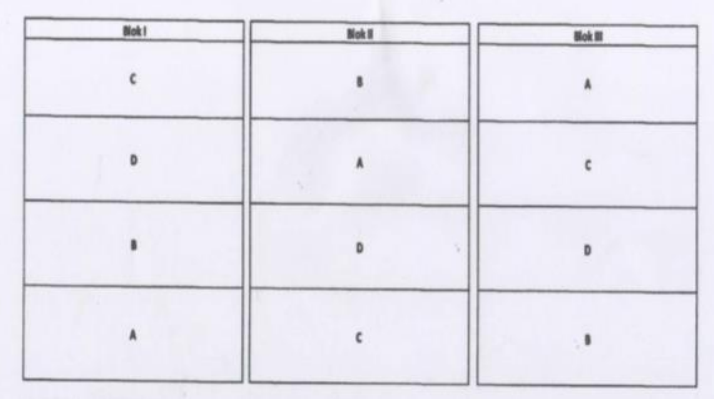

Fig. 1. Experimental plot design for forest species

\subsection{Measurement}

For early evaluation the study observed the early growth performance of forest species and socio-economic variables. We also observed the soil properties at initial condition or at the condition prior trial establishment. However, specifically, we did not observe the ecology variables after plot establishment, due to we suggested that the age of our agroforestry plot was not sufficient to influence the ecology properties of the plot.

The observation of growth was conducted at 5 (March 2020) and 11 months (September 2020) after planting. The number of live individual per species and per block was counted. Growth variables were observed for total height $(\mathrm{H})$ by measuring stick and collar diameter (D) by the caliper.

Observations of the social community used data collection methods by interacting directly with the object of research (in-depth interviews and field observations). Additional data was required such as secondary data obtained from related parties.

Observation of the community's economy, especially members of forest farmer groups who participated in our agroforestry project, collecting data from January 2019 to December 2020. All data on seasonal / agricultural crop yields are recorded and quantifies according to the type of crop and total weight during one planting period. 


\subsection{Data analysis}

We quantified the survival rate (Sv) of each forest species as percentage of live individual number per total number of individu that was observed. Height increment (Hi) and diameter increment (Di) were quantifies with the equation: $\mathrm{Hi}\left(\mathrm{cm}\right.$ year $\left.{ }^{-1}\right)=[\mathrm{H}$ at 11 months $-\mathrm{H}$ at 5 months $] / 2$ and Di $\left(\mathrm{cm}\right.$ year $\left.^{-1}\right)=[\mathrm{D}$ at 11 months $-\mathrm{D}$ at 5 months $] / 2$. ANOVA was performed to analyze the difference of growth based on difference of forest species. Prior of that, the normality of data was tested by Saphiro-Wilk test.

Data analysis in observing the socio-economic conditions of the community, using a qualitative descriptive method with the aim of disclosing occurrence or facts, circumstances, phenomena, variables and circumstances that occur during the activity by presenting what actually happened in the field. The data and information collected, both primary and secondary data, were analyzed using qualitative descriptive analysis. The data analyzed included data on education, income and economic activities of the community.

\section{Result and discussion}

\subsection{Soil properties}

The soil properties at initial condition (prior experiment) showed that the site had good fertility as was expressed with the high content of soil nutrient. It seems that the high content of soil nutrient was related to the maturity of peat which was sapric. Most peat matter including litter fragments in sapric was decomposed and through this processes the nutrient was released. However, the base saturation was low, while soil reaction was acid. The very high of CEC was the main factor that made this low base saturation, despite the content of available base cations were relatively high. Overall, it seem that the $\mathrm{pH}$ and soil nutrient content in our trial site were relatively higher than that in other previous trial site, such as at ICCTF trial site in Central Kalimantan, South Kalimantan, Riau and Jambi [18, 19].

Table 1. Soil properties at initial condition of trial site.

\begin{tabular}{|l|c|c|c|}
\hline \multicolumn{1}{|c|}{ Variables } & Unit & Value & Class[20] \\
\hline $\mathrm{pH} \mathrm{H}_{2} \mathrm{O}$ & - & 4.96 & Acid \\
\hline Organic-C & $\%$ & 39.2 & Very high \\
\hline Total $\mathrm{N}(\%)$ & $\%$ & 1.58 & Very high \\
\hline $\mathrm{C} / \mathrm{N}$ & - & 24.81 & High \\
\hline Available $\mathrm{P}$ & $\mathrm{ppm}$ & 24.5 & Very high \\
\hline $\mathrm{CEC}$ & $\mathrm{me} / 100 \mathrm{~g}$ & 121.00 & Very high \\
\hline Available $\mathrm{K}$ & $\mathrm{me} / 100 \mathrm{~g}$ & 0.48 & Moderate \\
\hline Available $\mathrm{Ca}$ & $\mathrm{me} / 100 \mathrm{~g}$ & 10.90 & High \\
\hline Available $\mathrm{Mg}$ & $\mathrm{me} / 100 \mathrm{~g}$ & 3.89 & High \\
\hline Available $\mathrm{Na}$ & $\mathrm{me} / 100 \mathrm{~g}$ & 0.49 & Moderate \\
\hline Base saturation & $\%$ & 13.02 & Low \\
\hline
\end{tabular}

\subsection{Forest Species Growth}

The range of survival rate (Sv) of all species 5 months (March 2020) and 11 months (September 2020) after planting were $79.4-82.9$ and $56.7-72.4 \%$. The best Sv was in Geronggang (72.4\%) consistently, but insignificantly different $(p>0.05)$ than those in other species (Fig. 2). The Sv of studied species in present study generally was less than 
that in previous study. An exception, the Sv of present study was relatively better than the $\mathrm{Sv}$ of Balangeran in agroforestry trial in Central Kalimantan (Table 1.).

The mortality rate of all studied species was relatively high, which was the mortality rate in about one year period could reach more than $25 \%$. We suggested that the high mortality in the field due to the period of first one year after plantation was the most severe period for seedling to survive in new environment. Therefore, several seedlings which could not well adapt would be died. We also suggested that the low survival in present study seem related to the several practices of farmer. As the example, the method that was commonly used by farmer to treat weeds was through foliar spray. Through this method, the herbicide which was sprayed had possibility to off-target. It means not only spray weed but also the seedling of forest species (tree seedling). Therefore, some tree seedlings which were accidentally sprayed also would be died.

As the native species of tropical peat swamp forest, all three studied species has high value for biodiversity and other ecology aspect. In order to maximize this ecology value, the stock of the tree at the field must be increased. Therefore, the replanting after 11 months must be undertaken and to hinder the possibility of plant death due to farming practice, the communication among stakeholders must be improved.

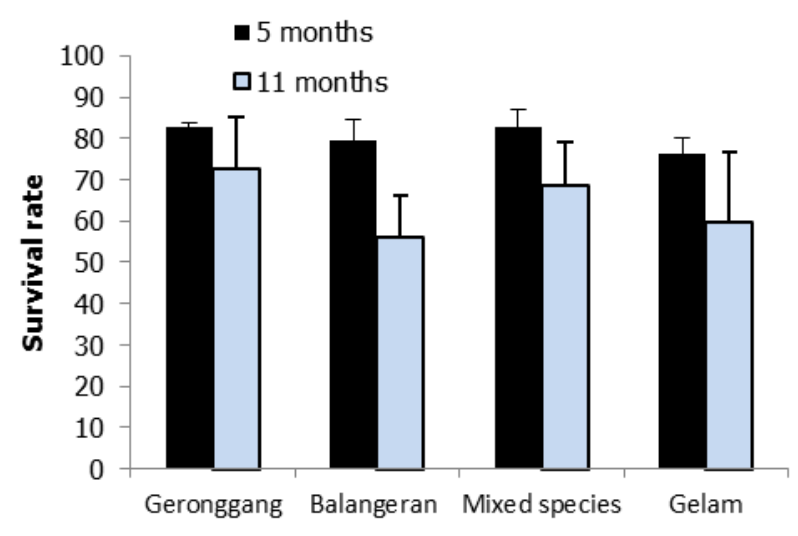

Fig. 2. The survival rate of Geronggang, Gelam and Balangeran in agroforestry trial in peatland of KHDTK Kepau Jaya, Kampar, Riau

The ranges of height of all species at 5 and 11 months were $88.8-113.6 \mathrm{~cm}$ and $148.8-$ $195.1 \mathrm{~cm}$; while the ranges of diameter were $0.92-1.03 \mathrm{~cm}$ (5 months) and $1.94-2.53 \mathrm{~cm}$ (11 months). Generally, at the age of 5 and 11 months, the best of height and diameter was showed by Gelam but insignificantly different $(p>0.05)$ than other species. 

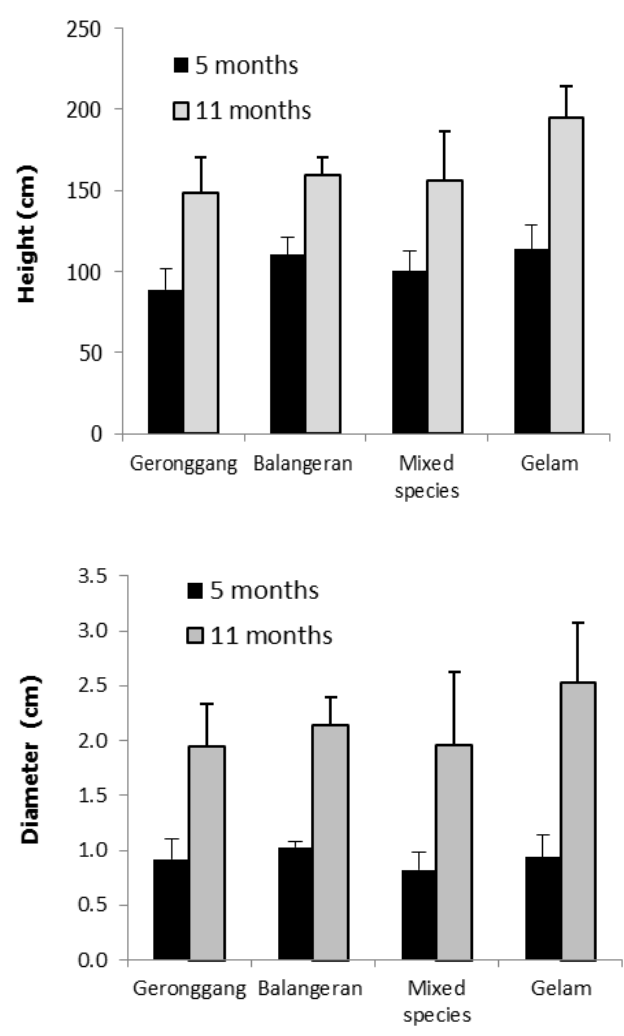

Fig. 3. The early growth of Geronggang, Gelam and Balangeran in agroforestry trial in peatland of KHDTK Kepau Jaya, Kampar, Riau

Based on the increasing of growth from 5 to 11 months, the early best growth increment was showed by Gelam (height increment $=163 \mathrm{~cm} \mathrm{year}^{-1}$ and diameter incerement $3.2 \mathrm{~cm}$ year $\left.^{-1}\right)$ (Fig. 3), but also insignificantly different $(\mathrm{p}>0.05)$ than other species. This height increment of Gelam was 1.36, 1.67 and 1.47 folds higher than those in Geronggang, Balangeran and mixed species, while for its diameter increment was $1.55,1.39$ and 1.39 folds higher than those in Geronggang (119.91 cm year $\left.{ }^{-1}\right)$, Balangeran $\left(97.45 \mathrm{~cm}_{\text {year }}{ }^{-1}\right)$ and mixed species $\left(110.44 \mathrm{~cm}_{\text {year }}{ }^{-1}\right)$.
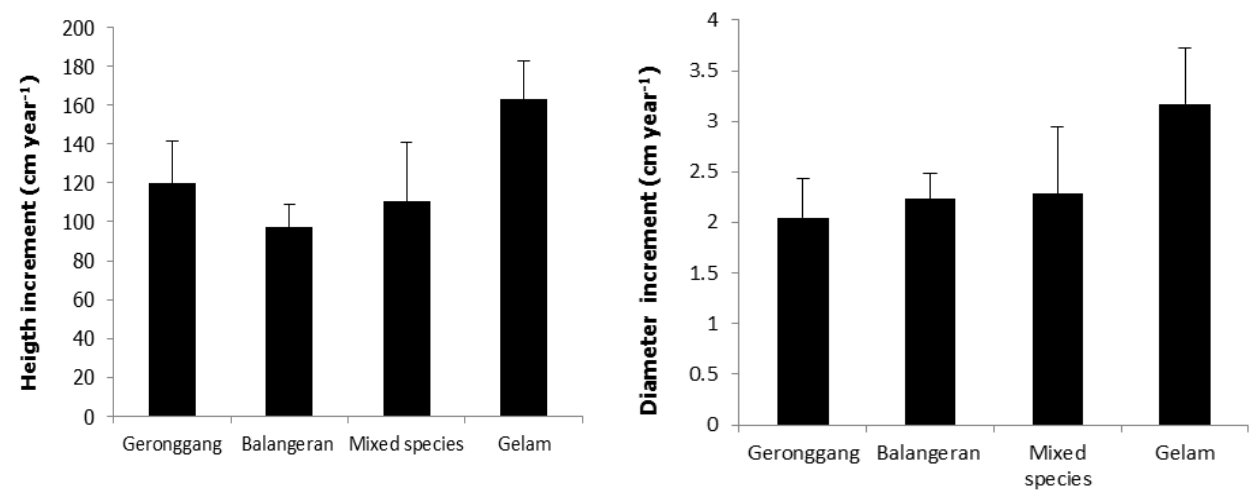

Fig. 4. The early growth increment of Geronggang, Gelam and Balangeran in agroforestry trial in peatland of KHDTK Kepau Jaya, Kampar, Riau 
The early growth rate of studied species generally was in the growth rate range of previous studies (Table 2.). Furthermore, due to the soil fertility of trial site was relatively high (Table 1), we had the hope that the growth rate of all studied species will be better at the next stage when the species was more well adapted to the field environment. Beside of that, we also hope that the application of fertilizer by the farmer to their crop in our agroforestry trial will give positive effect on increasing soil fertility and further the growth rate of tree seedling in next stage as was shown by Balangeran in agroforestry in Central Kalimantan. The study of Tata \& Prajadinata [21] showed that the growth rate of Balangeran in agroforestry $\left(120 \mathrm{~cm}\right.$ year $\left.^{-1}\right)$ was better than that in secondary forest $(<100$ $\mathrm{cm}$ year $\left.^{-1}\right)$.

Table 2. Survival and growth rate the three studied native tree species in some previous studies in peatland.

\begin{tabular}{|c|c|c|c|c|c|}
\hline Species & $\begin{array}{c}\text { Age } \\
\text { (months) }\end{array}$ & $\begin{array}{c}\text { Survival } \\
(\%)\end{array}$ & $\begin{array}{c}\text { Height } \\
\text { increments } \\
\left(\mathrm{cm} . \text { year }^{-1}\right)\end{array}$ & Location & References \\
\hline Gelam & - & - & $<200$ & South Sumatra & [22] \\
\hline Gelam & 120 & & 68 & South Sumatra & [23] \\
\hline Geronggang & 37 & 67 & 175 & Riau & [24] \\
\hline Geronggang & & & $118-289$ & Central Kalimantan & [25] \\
\hline Geronggang & 2.3 & 93 & - & Sabah, Malaysia & [26] \\
\hline Geronggang & 18 & $>80$ & $100-200$ & Riau & [27] \\
\hline Geronggang & 24 & 72.7 & 197 & Riau & [28] \\
\hline Balangeran & 8 & 4 & - & Central Kalimantan & [29] \\
\hline Balangeran & 12 & $\begin{array}{l}>80 \\
(\mathrm{SF}) \\
<50 \\
(\mathrm{AF})\end{array}$ & $\begin{array}{c}<100(\mathrm{SF}) \\
120(\mathrm{AF})\end{array}$ & $\begin{array}{c}\text { Central Kalimantan } \\
(\mathrm{SF}=\text { secondary } \\
\text { forest, } \mathrm{AF}= \\
\text { agroforestry trial })\end{array}$ & [21] \\
\hline Balangeran & 48 & 95 & 150 & Central Kalimantan & [24] \\
\hline
\end{tabular}

\subsection{Socio condition of community}

Pratiwi [30] in his research states the level of education is one of the factors that influence community participation. The higher level of education that has been taken has an effect on the high ability of the community to receive and filter knowledge. Based on the level of education, the data obtained shows that most of the 31 respondents were only able to complete the education level up to Elementary School (SD). Respondents who were able to complete education up to the Junior High School (SLTP) level were 9 respondents, and Senior High School (SLTA) level were 9 respondents. There were no respondents who were able to complete formal education to college education level (PT), as shown in figure 5 . 


\section{Education Level of KTH Members}

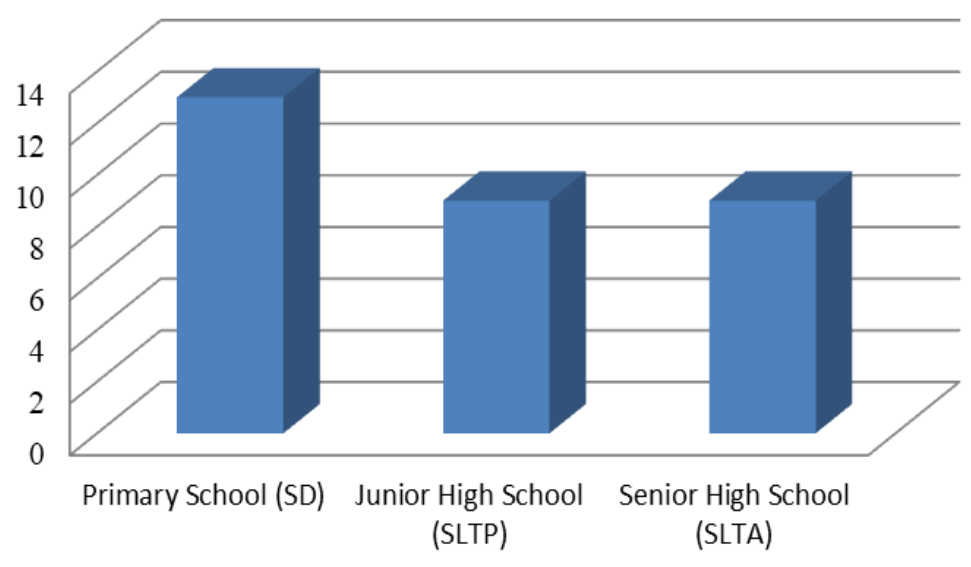

Fig. 5. The education level of forest farmer group members

The age of the respondents in this study varied widely. The lowest age or the youngest is 19 years old. Meanwhile, the oldest or highest age is 66 years old. Some respondents are members of farmer group who are of productive age, the average age of the respondents is 37 years. Respondents of productive age have the potential to carry out activities maximally so that they can increase their income and support their family's economy. The dominant age of the community / respondent who is classified as productive is expected to have a good influence. Data on the age of farmer group members is presented in Figure 6 .

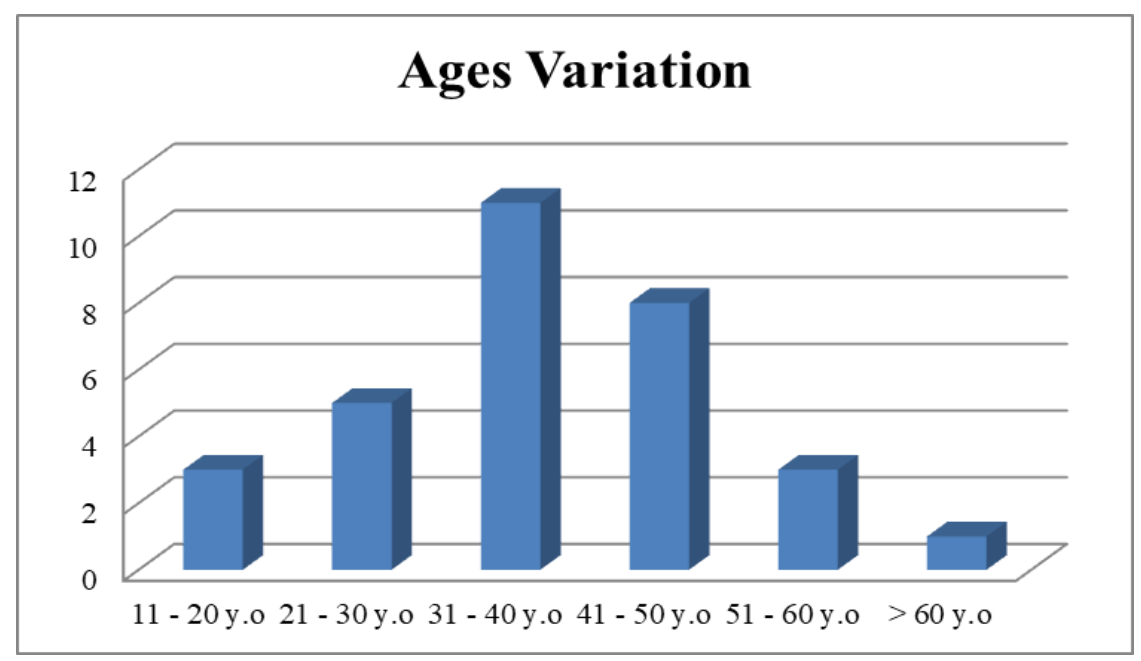

Fig. 6. Ages variation of forest farmer group members

\subsection{Economy Improvement of the Community}

In community empowerment activities with agroforestry scheme, the real impact that can be obtained on improving the community's economy from the yields of seasonal crops. It 
can be benefited in a relatively short time. The types of seasonal plants used by the community look at the conditions in the field. Farmers' expertise is also one of the considerations in selecting the types of plants used. In addition, all types of plants selected pay attention to the designation of the location of the activity which is not only for research activities but also as a source of feed for honey-producing bees. These types of plants are Luffa, Melon, Chili, Corn, Cucumber and Cassava.

From each type of annual crop, harvest data were obtained for each one planting period. In addition, data on sales of seasonal crops harvested during one planting period were also obtained. The types of seasonal plants used in the observation were Chili, Melon and Luffa. Other types of plants such as corn, cucumber and cassava were only used as food for the group during their activities at the demonstration plot. Obtained data from three types of seasonal plants observed, in one planting period the chili plants produced a harvest weight of $882 \mathrm{~kg}$ and the type of melon plant produced a harvest weight of $6169 \mathrm{~kg}$. While Luffa plant produces a harvest weight of $1211 \mathrm{~kg}$ [31]. Based on these data, the three types of plants were deemed suitable for use in the demonstration plot area using an agroforestry scheme. Harvest weight data can be seen in Figure 7.

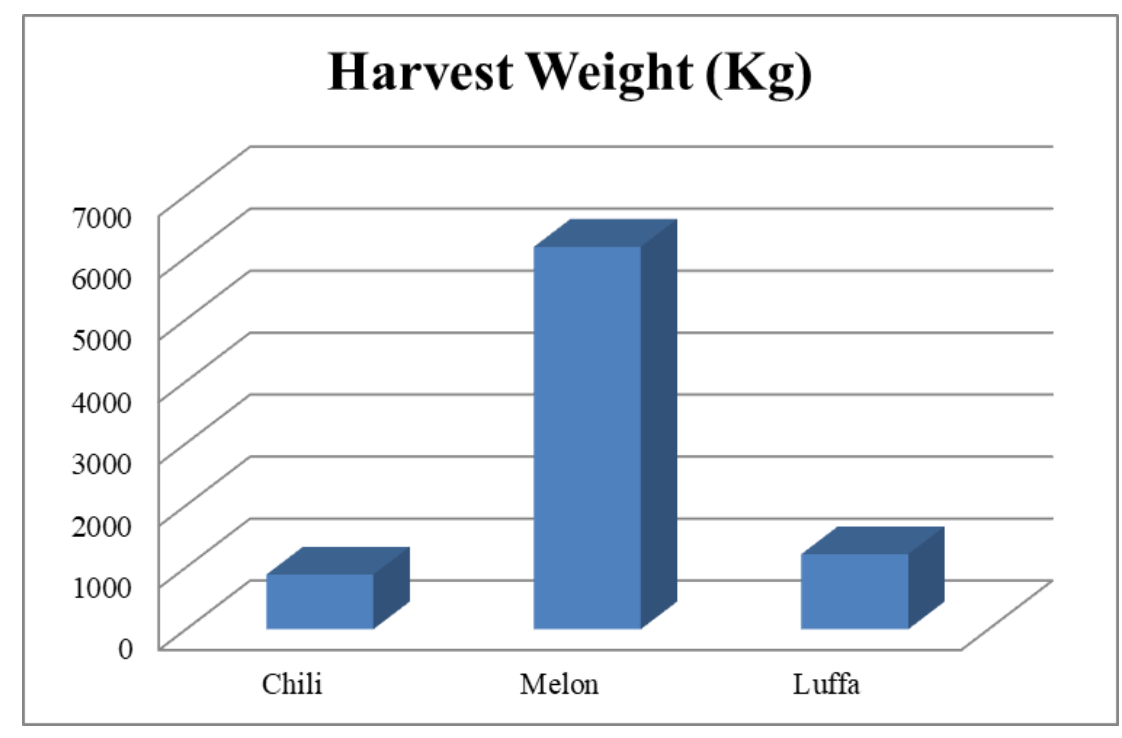

Fig. 7. The number of annual crops harvested in one planting period 


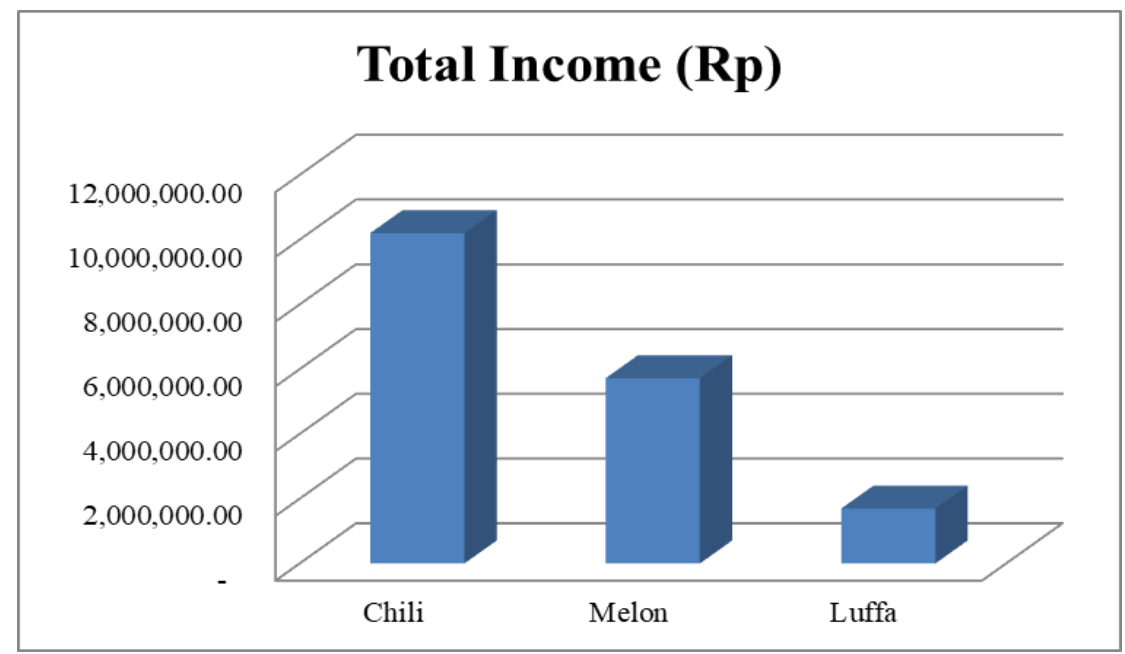

Fig. 8. Total income from seasonal crop harvests

Based on Figure 8, data shows that the largest income of the community is obtained from the seasonal crop yields of chili, which is $25,510,500$ IDR. It is influenced by the market price of chili which is increasing during the harvesting process. From the yields of the three types of seasonal crops, the community was able to earn an average income of 6,000,000 IDR.

To determine the increase in the community's economy, it can be seen from the comparison of community income before and after the implementation of community empowerment activities. The income of the community before the implementation of community empowerment activities is between 1,500,000 IDR to 2,000,000 IDR/month [31]. After the implementation of community empowerment activities, the average income earned by the community from harvesting seasonal crops is $6.000 .000 \mathrm{IDR} / \mathrm{month}$. Based on this comparison, it can be concluded that the people's income has increased.

Apart from the economy, community empowerment activities also generate benefits in social aspects. One of which is the decrease in forest resource use conflicts. It was indicated by the absence of hotspots for forest and land fires, which differed from the previous years. With the existence of community empowerment activities, group members are more often in the area. It can protect the forest area from land occupation actions by irresponsible parties. Beside of those results, we also observed that during this agroforestry activity, the intensity of forest disturbance by the local community around KHDTK was relatively reduced. It is important to manage and increase those diverse benefits in further years, so the existing of agroforestry in order to improve degraded peat forest and resolve the social conflict will be real. To realize this target, the good and intensive communication among stakeholders is one of important parts that must be continuously implemented in the field.

\section{Conclusion}

In this early evaluation the growth of the native tree species was relatively promising. Community empowerment by using agroforestry schemes is able to increase the income of the community around the forest area, from the initial 2 million IDR (before any activities) to an average of 6 million IDR. Aside from that, during this agroforestry activity, the intensity of forest disturbance by the local community around Forest Area With Special Purpose was relatively reduced. 


\section{References}

1. R. B. Edwards, R. L. Naylor, M. M. Higgins, and W. P. Falcon. World Dev. 127 (2020). doi: 10.1016/j.worlddev.2019.104717.

2. K. Gultom. J. Int. Relations. 2, 2:33-43(2016).

3. World Bank. Indonesia Economy Quarterly: Investing in People. (2019).

4. D. Charles. Scientists on Indonesia's polluting haze - Controlling the peatland fire is a matter of law and order. Sep. (2019).

5. FWI. Potret keadaan hutan indonesia. Forest Watch Indonesia. Bogor (2014).

6. Wahyunto et al. Atlas lahan gambut terdegradasi Pulau Sumatera. Badan Penelitian dan Pengembangan Pertanian. Bogor (2013).

7. C. Ward et al. Reg. Enviromental Chang. 21, 1(2021).

8. E. Martin, M. Ulfa, A. Silalahi, and B. Winarno. Agroforestry tradisional sebagai basis pengembangan hutan rakyat: Kasus di Kabupaten Lahat Sumatera Selatan, in Prosiding Temu Lapang dan Ekspose Hasil-Hasil Penelitian UPT Badan Penelitian dan Pengembangan Kehutanan Wilayah Sumatera. pp. 133-146(2003),

9. C. Mbow, M. Van Noordwijk, E. Luedeling, H. Neufeldt, P. A. Minang, and G. Kowero. Environ. Sustain. 6. p. 61-67(2014). doi: 10.1016/j.cosust.2013.10.014.

10. R. P. Nair. Agroforestry: Trees in Support of Sustainable Agriculture, no. June. Elsevier Inc. (2013).

11. Sahuri. J. Anal. Kebijak. Kehutan. 16, 2:105-115(2019). [Bahasa Indonesia]

12. Suryanto, T. S. Hadi, and S. Endang. Eds. Mengenal Shorea balangeran, in Budidaya Shorea balangeran di Lahan Gambut, Banjarbaru. p. 1-4(2012). [Bahasa Indonesia]

13. Y. Aprianis. The Possibillity of alternative wood for pulp in The Proceeding of Research Finding: Opputunities and Challanges of The Development of Environment and Forestry in Riau. p. 1-11(2016).

14. Danu and A. Junaedi. The Propagation of Geronggang Seedling, in The book chapter of geronggang, 1st ed., Y. Rochmayanto and E. Novriyanti, Eds. Yogyakatta: Diandra Kreatif. p. 45-56(2019).

15. A. Junaedi. Mengenal Geronggang in Bunga Rampai Geronggang: Jenis Lokal Potensial Bumi Lancang Kuning, Y. Rochmayanto and E. Novriyanti, Eds. Diandra Kreatif. p. 15-44(2019). [Bahasa Indonesia].

16. Y. F. Arifin, S. Hamidah, and Y. F. Arifin. Ecological Analysis of Gelam ( Melaleuca cajuputi ). 07, 3:77-79(2016).

17. R. Manurung, A. Widiana, and T. Taufikurahman. Composition of Leaf Oil of Gelam ( M. leucadendra ( L .) L .) Growing in Various Peat Swamp Regions of Central Kalimantan Indonesia Composition of Leaf Oil of Gelam ( M . leucadendra ( L .) L .) Growing in Various Peat Swamp Regions of Central Kalimantan. no. December 2019(2015).

18. Hikmatullah and Sukarman. J Trop. Soils. 19, 3:131-141(2014). doi: 10.5400/jts.2014.19.3.131.

19. H. Husnain, I. G. P. Wigena, A. Dariah, S. Marwanto, P. Setyanto, and F. Agus. Mitig. Adapt. Strateg. Glob. Chang. 19, 6:845-862(2014). doi: 10.1007/s11027014-9550-y.

20. Eviati and Sulaeman. Manual for Chemical Analysis of Soil, Plant and fertilize, 2nd ed. Bogor: Research Institute for Soil (2009).

21. H. L. Tata and S. Prajadinata. Rehabilitasi Lahan Gambut Terdegradasi dengan Pola Partisipatif in Prosiding Seminar Nasional Benih Unggul untuk Hutan Tanaman, Restorasi Ekosistem dan Antisipasi Perubahan Iklim, no. November 2014. p. 303-312(2014). [Bahasa Indonesia] 
22. H. Siahaan and A. Sumadi. J. Penelit. Hutan Tanam. 11, 3:29-40(2015).

23. H. Siahaan and S. Islam. Teknik Pembudidayaan Gelam. Palembang (2010). [Bahasa Indonesia]

24. H. Daryono. J. Anal. Kebijak. Kehutan. 6,2:71-101(2009).

25. H. Saito et al. J. For. Res. 2, 2:1-10(2005).

26. A. R. Mojiol, Wahyudi, and N. Nasly. J. Wetl. Manag. 2, 1:66-78(2014).

27. A. Junaedi. Growth Performance of Three Native Tree Species for Pulpwood Plantation in Drained Peatland of Pelalawan District, Riau. Indones. J. For. Res. 5, 2:119-132(2018). doi: 10.20886/ijfr.2018.5.2.119-132.

28. H. Gunawan. Peatland restoration in Riau Biosphere Reserve, Indonesia, in National Proceeding of Biology Seminar. p. 29-37(2013).

29. W. Giesen and P. van der Meer. Guidelines for the Rehabilitation of degraded peat swamp forests in Central Kalimantan - Master Plan for the Conservation and Development of the Ex-Mega Rice Project Area in Central Kalimantan, no. 9. Mott MacDonald(2009).

30. M. R. Pratiwi. Analisis Tingkat Partisipasi Masyarakat Terhadap Pelaksanaan Program Desa Vokasi Di Desa Pulutan Wetan Kecamatan Wuryantoro Kabupaten Wonogiri. Universitas Muhammadiyah Surakarta (2015).

31. A. S. Yunianto and E. Sutrisno. Pembentukan kelompok tani hutan sebagai upaya resolusi konflik melalui konsep pemberdayaan masyarakat di KHDTK Kepau Jaya. Unri Conf. Ser. Community Engagem. 1. p. 74-82(2019). doi: 10.31258/unricsce.1.74-82. [Bahasa Indonesia]. 